\title{
$\mathrm{LMO}$ 격리 포장에서 해충저항성벼(Bt-T)가 비표적 곤충다양성에 미치는 영향
}

\author{
오성덕 $^{1 * *} \cdot$ 박수윤 $^{1 * *} \cdot$ 장안철 $^{1} \cdot$ 임명호 $^{1} \cdot$ 박순기 $^{2} \cdot$ 서상재 $^{2 *}$
}

${ }^{1}$ 농촌진흥청 국립농업과학원 생물안전성과, ${ }^{2}$ 경북대학교 농업생명과학대학 응용생명과학부

\section{Influences of Insect-Resistant Genetically Modified Rice (Bt-T) on the Diversity of Non-Target Insects in an LMO Quarantine Field}

\author{
Sung-Dug Oh ${ }^{1 * *}$, Soo-Yun Park ${ }^{1 * *}$, Ancheol Chang ${ }^{1}$, Myung-ho Lim ${ }^{1}$, Soon Ki Park ${ }^{2}$, and Sang Jae Suh ${ }^{2 *}$ \\ ${ }^{1}$ Department of Agricultural Biotechnology, National Institute of Agricultural Sciences, RDA, Jeonju, 54874, Republic of Korea \\ ${ }^{2}$ School of Applied Biosciences, Kyungpook National University, Daegu, 41566, Republic of Korea
}

\begin{abstract}
This study was conducted to develop environmental risk assessments and biosafety guides for insect-resistant genetically modified rice in an LMO (Living Modified Organism) isolation field. In the LMO quarantine area of Kyungpook National University, the species diversities and population densities of non-target insects found on insect-resistant genetically modified rice (Bt-T), rice resistant to Cnaphalocrocis medinalis, and non-GM rice (Dongjin-byeo and Ilmi-byeo) were investigated. The Bt-T plants were, therefore, evaluated under field conditions to detect possible impacts on above ground insects and spiders. In 2016 and 2017, the study compared transgenic rice and two non-GM reference rice, namely Dongjin-byeo and Ilmi-byeo, at Gunwi. A total of 9,552 individuals from 51 families and 11 orders were collected from the LMO isolation field. From the three types of rice fields, a total of 3,042; 3,212; and 3,297 individuals from the Bt-T, Dongjin-byeo, and Ilmi-byeo were collected, respectively. There was no difference between the population densities of the non-target insect pests, natural enemies, and other insects on the Bt-T compared to non-GM rice. The data on insect species population densities were subjected to principal component analysis (PCA) without distinguishing between the three varieties, namely GM, non-GM, and reference cultivar, in all cultivation years. However, the PCA clearly separated the samples based on the cultivation years. These results suggest that insect species diversities and population densities during plant cultivation are determined by environmental factors (growing condition and seasons) rather than by genetic factors.
\end{abstract}

Keywords Insect-resistant genetically modified rice (Bt-T), Biosafety, Non-target insect diversity

Received on September 13, 2018. Revised on September 20, 2018. Accepted on November 2, 2018.

* Corresponding Author (E-mail: sjsuh@knu.ac.kr, Tel: +82-53-950-7767 Fax: +82-53-950-6758)

** The first two authors contributed equally to this work

\section{서 언}

GM작물(Genetically modified crops, 유전자변형작물)은 1994년에 상업화 이후, 생명공학기술을 이용한 GM작물 재배면 적이 증가하여 2017년에는 24개국에서 189.8백만 헥타르의 면 적에서 재배되었으며, 세계 전체 종자시장의 $30 \%$ 를 차지하고 있다. GM작물은 2017년을 기준으로 40개 국가에서 사료 및 식품, 환경 방출에 대한 승인이 이루어졌으며, 29개 작목, 498개 의 이벤트에 대해 승인이 이루어졌다(James 2018). GM작물은 농업 생산량의 증가와 농약 사용 절감에 따른 재배 용이와 생산량 증가에 따른 농가 소득 증대 및 농업 환경 피해 감소 및 이를 통한 온실가스 감소 등 다양한 이점이 있다고 알려져 있지만 (James 2018, Lee et al. 2012), GM작물의 안전한 이용과 인체와
환경에 대한 위해성을 방지하고자 세계 각 나라들은 자국에 적합한 유전자변형생물체(genetically modified organism; GMO) 안전 관리 체계를 구축하였으며, 특히 바이오 안정성 의정서 (Cartagena Protocol on Biosafety)를 통해 $\mathrm{GMO}$ 에 대한 국가 간의 안전관리와 협력을 도모하고 있으나, $\mathrm{GM}$ 작물 재배 농경지 주변의 생태계 위해성과 농업환경 및 GM작물의 식품 섭취에 의한 인체 안전성에 대한 우려도 꾸준히 문제시 되고 있다(Lee 2017). 생태계의 영향 평가는 생태계를 구성하는 생물종에 대한 정량 적으로 분석하는 생물다양성(Biodiversity) 조사를 기반으로 하 며, 생물다양성은 특정한 생태계에서 종의 수와 분포, 형태 등의 종 상호간 관계를 보여주는 종 다양성(Species diversity), 서식지 내의 공생 또는 경쟁하며 먹이사슬을 구성하는 생태적 기능을 보여주는 생태계 다양성(Ecosystem diversity)으로 나누어진다 
(Choi et al. 2015). 백만종이 넘는 곤충은 생태적으로 다양하며, 먹이 사슬 구성에서 수적으로 우위를 차지하고 있다(Price 1997). 생태계 먹이 사슬의 초기 단계에서 곤충 종의 구성변화는 생태계 의 특성을 보여주는 지표이며, 장기적인 생태계 변화를 분석함에 중요한 요소이다(Gullan \& Cranston 2005). 고부가가치의 기능 성 농산물 수요 시장의 다변화 요구 등으로 $\mathrm{GM}$ 작물의 개발 건수와 재배면적이 증가하고 있는 만큼 개발된 $\mathrm{GM}$ 작물의 상용 화를 위해서는 재배 농경지와 주변 생태계에 미치는 영향에 대한 작물 재배 환경 수준의 안전성 평가가 요구되고 있다 $(\mathrm{Oh}$ et al. 2014, Lee 2017).

밀, 옥수수와 함께 세계 3대 곡류인 벼(Oryza sativa L.)는 아시아에서 주식인 중요한 작물이다(Qin et al. 2009, Lee et al. 2015). 벼에는 3대 영양소인 탄수화물, 지방, 단백질이 함유되 어 있으며 이외 무기질, 식이섬유, 비타민 등이 함유되어 영양학 적으로 우수하며, 비만 및 혈중 콜레스테롤을 저하시키는 효과가 있는 것으로 보고되었다(Son 2001, Lee et al. 2015). 기존 재배 품종의 특정 영양 성분 강화하거나 재배의 용이성을 위해서 병해충에 저항성을 지닌 유전자를 도입된 $\mathrm{GM}$ 벼들이 많이 개발 되고 있다. 국내에서는 제초제 저항성, 병저항성, 가뭄저항성 및 레스베라트롤 생합성 $\mathrm{GM}$ 벼 등의 안전성 평가를 위한 $\mathrm{LMO}$ 격리포장에서 실험 재배도 하였지만, 현재까지 상업적 목적의 $\mathrm{GM}$ 작물이 재배되고 있지는 않다(Oh et al. 2014). 근래에 다양한 특성의 $\mathrm{GM}$ 벼들에 대한 안전성 평가 연구로 $\mathrm{LMO}$ 격리 포장 재배 시에 발생하는 곤충상 발생 비교 및 해충 양상에 대한 보고들은 있으나(Kim et al. 2010, Bae et al. 2012, Choi et al. 2015, Oh et al. 2017), GM벼의 재배 연차 간의 비표적 곤충상 조사 및 비교 분석에 관한 연구는 보고 된 바 없다.

본 연구에서는 토양 세균인 Bacillus thuringiensis에서 유래한 해충저항성 유전자 $(m c r y l A c l)$ 를 동진벼에 도입시킴으로써 혹 명나방(Cnaphalocrocis medinalis)에 대하여 살충성을 나타내 는 해충저항성 $\mathrm{Bt}$ 벼(Lee et al. 2015)의 환경위해성 평가 항목 중 거미를 포함한 천적과 해충 등에 미치는 영향을 평가하기 위해 해충저항성 $\mathrm{Bt}$ 벼와 모본인 동진벼 및 재배품종인 일미벼를 재배한 LMO 격리 포장에서 혹명나방 등 표적 해충을 제외한 비표적 곤충상의 발생 및 변화 양상을 연차간 비교 분석하였으며, 본 연구를 통해 국내 개발 $\mathrm{GM}$ 벼의 환경위해성 안전관리 지침서 작성시에 기초 자료로 제공하고자 한다.

\section{재료 및 방법}

본 연구의 시험재료인 해충저항성 $\mathrm{Bt}$ 벼(Bt-T, 2016년T5 세대, 2017년 T6세대)와 모품종인 동진벼 및 일미벼를 경북대학교 군위 $\mathrm{LMO}$ 격리포장에서 $18 \mathrm{~m}^{2}$ 의 면적(40주×10줄, 400 주/1반 복)을 3반복 난괴법으로 배치하여 2016년과 2017년에 재배하였 다(경북 군위군, RDA-가A-2015-049). 벼의 재배 방법은 농촌진 흥청의 시험 표준재배법을 기준으로 하였으며, 공시계통인 해충 저항성 $\mathrm{Bt}$ 벼와 동진벼 및 일미벼 종자를 육묘용 플러그 트레이 (50공)에 2016년에는5월 9일에 파종한 후 6월 10일에 LMO 격리포장에 정식하였고, 2017년에는 5월 3일에 파종한 후 6월 3일에 LMO 격리포장에 정식하였다.

곤충 조사는 해충저항성 $\mathrm{Bt}$ 벼(Bt-T)와 동진벼 및 일미벼를 대상으로 2016년에는 성장기(2016년 7월 1일)부터 수확 직전 (2016년 10월 9일)까지 2주 간격으로 총 8회에 걸쳐 실시하였고, 2017년도는 성장기(2017년 6월 30일)부터 수확 직전(2017년 10 월 7일)까지 2주 간격으로 총 8 회에 걸쳐 실시하였다. 채집은 각 품종별 3 반복으로 수행하였고, 해충저항성 $\mathrm{Bt}$ 벼(Bt-T)와 동진 벼 및 일미벼 간의 표적 해충을 제외한 천적과 해충 및 기타 곤충을 대상으로 기능군별 발생양상을 분석하였다. 각 실험구별 채집조사는 조사자간의 편차를 최소화와 곤충 채집 효율의 증대 하기 위하여 총채벌레 등의 미소 곤충이 포집될 수 있는 채집망을 부착된 지름 9인치 엔진식 흡충기(Agricultural Backpack 2-Cycle Aspirator, M1612, John W. Hock Company)로 왕복 이동하면서 각 실험구의 1 반복당 벼 250 주씩 상하단 부위를 흩는 식으로 곤충을 흡충한 후, 지퍼팩에 채집된 곤충을 담은 후 에틸아세테이 트(Ethyl Acetate)로 살충하였다.

채집된 곤충 중에 벼의 해충으로 알려진 애멸구(Laodelphax striatellus), 흰등멸구(Sogatella furcifera), 벼멸구(Nilaparvata lugens)와 번개매미충(Maiestas dorsalis), 꼭지매미충(Macrosteles striifrons) 등의 매미충류와 벼밤나방(Sesamia inferens)과 벼애 나방(Naranga aenescens)이 포함된 나방류 및 빨간촉각장님노 린재(Trigonotylus caelestialium), 애긴노린재(Nysius plebejus) 등이 포함된 노린재류로 구분된 곤충들을 해충군으로 분류 선정 하였으며, 이들 해충군에 대한 천적을 천적군(거미 포함)으로 분류 선정하였다. 천적군과 해충군을 제외한 곤충들을 기타 곤충 군으로 분류 선정하였다(Choi et al. 2015). 벼에 대한 곤충의 기능별로 천적군(거미 포함), 해충군, 기타 곤충군으로 구분하여 계수하였으며, 해충군은 종(species) 수준에서, 천적군과 기타 곤충군은 과(family) 수준에서 동정 계수하였다. 채집된 곤충의 
조사 결과에 대한 통계 분석은 SPSS (23.0.0 for Windows, Rel.23.0, 2015. Chicago: SPSS Inc.)를 사용하여 $p<0.05$ 수준으 로 ANOVA와 Duncan test로 평균간의 유의성 여부를 검정하였 고, 채집된 곤충의 기능군별로 우점도 지수(dominance index, DI; McNaugton's dominace index) 및 풍부도 지수(richness index, RI; Margalef species richness index), 다양도 지수(diversity index, H'; Shannon-Weaver diversity index), 균등도 지수(evenness index, EI; Pielou index)를 계산하였다(Choi et al. 2015).

재배 품종 및 시기에 따른 곤충상의 변화를 더 다양하게 분석하기 위해 최근에는 작물의 다양한 성분 조성에 따른 품질을 평가하고 우수 품종을 선정하는 연구 등에 활용되고 있는(Lee et al. 2017) 주성분 분석을 수행하였다(SIMCA-P version 12.0; Umetrics, Umeå, Sweden). 모든 변수에 대한 데이터 값은 주성분 분석을 수행하기 전에 단위 분산 방식(unit variance scaling)으로 표준화 (standardization)하였고, 또한 추가 가공을 하지 않기 때문에 복잡한 데이터의 변이성을 1 차적으로 확인하기에 적합한 방법으 로 여겨지고 있다. 분석 결과는 샘플간 변이를 시각화 할 수 있는 score plot과 그 변이를 설명 할 변수로 구성된 loading plot으로 나타내었다.

\section{결과 및 고찰}

2016년과 2017년 2년동안 벼의 성장기에서 종자 수확 직전까 지 약 100 일간 해충저항성 $\mathrm{Bt}$ 벼(Bt-T)와 모품종인 동진벼 및 재배품종인 일미벼를 재배한 포장에서 연도별로 총 8 회에 걸쳐 채집된 곤충을 해충, 천적 및 기타 곤충의 기능군별 발생현황을 비교 분석하였다. 조사기간 11 목 51 과 9,552 개체의 곤충류와 거미류가 채집되었으며, 기능군별로는 해충류 7 목 17 과 4,116개체, 천적류 6 목 24 과 2,479 개체, 기타 곤충류 3 목 13 과 2,957 개체가 채집되었다. 품종별로 해충저항성 $\mathrm{Bt}$ 벼(Bt-T) 재배지에서 3,042 개체, 모품종인 동진벼 재배지는 3,213 개체 및 재배품종인 일미 벼에서 3,297 개체가 채집되었다(Table 1). 해충은 2016년에는 16 과 1,805 개체가, 2017년에는 14 과 2,311개체가 조사되어 2017 년에 조사밀도가 증가하였다. 2016년에는 멸구과(Delphacidae) 의 발생이 가장 많았으며 전체 밀도의 대부분을 차지하였다. 2017 년에는 2016년에 발생밀도가 낮았던 매미충과(Cicadellidae)의 발생밀도가 매우 높아졌으며, 또한 총채벌레과(Thripidae)의 발 생도 높게 나타났고, 멸구류의 발생은 비슷한 수준을 유지하였다. 포식성 및 기생성 곤충과 거미류를 포함한 천적류는 2016년에는 곤충류는 10 과 575 개체, 거미류는 9과 406개체로 총 981 개체가
조사되었으며, 2017년에는 곤충류가 10과 992개체, 거미류가 10 과 506 개체로 총 1,498 개체가 조사되어 천적곤충류 및 거미류 모두 2017년에는 증가한 경향을 보였다. 곤충천적류 중에서는 특히 좀벌과(Eulophidae)의 발생이 2017년에 매우 증가하였으 며, 반면 반날개과(Staphylinidae), 납작먹좀벌과(Platygastridae) 및 맵시벌과(Ichneumonidae)는 감소한 경향을 보였다. 거미류에 서는 가게거미과(Agelenidae) 및 깡충거미과(Salticidae)가 2017 년에 다소 증가한 경향을 보였으며, 기타 거미류는 비슷한 발생양 상을 나타내었다. 해충 및 천적을 제외한 기타 곤충류에서는 2016 년에는 11 과 1,472 개체가, 2017 년에는 12 과 1,485 개체가 조사되 어 비슷한 발생량을 보였다. 그 중에서 잎벌레과(Chrysomelidae) 와 모기과(Culicidae)는 2016년보다 2017년에 감소한 경향을, 알꽃벼룩과(Helodidae), 바구미과(Curculionidae), 장다리파리 과(Dolichopodidae) 및 물가파리과(Ephydridae) 곤충들은 증가 한 경향을 보였다. 이와 같이 전반적으로 2017년이 2016년보다 해충 및 천적의 발생량이 증가하였으며, 조사 년도에 따라 곤충종 류에 따라 발생량의 차이를 보이기도 하였다.

2년간의 조사기간 동안 채집된 곤충들은 기능군별로 해충군, 천적군, 기타 곤충군으로 구분하여 계수하였다. 채집된 전체 개체들에서 기능군별 비중은 해충 $43.0 \%$, 천적 $26.0 \%$, 기타곤충 $31.0 \%$ 로, 2 년간의 조사 기간 동안에 해충의 발생밀도가 매우 높았다. 해충군에서는 애멸구(Laodelphax striatellus) 등의 멸구 과(Delphacidae), 번개매미충(Maiestas dorsalis) 등 매미충과 (Cicadellidae)와 벼줄기굴파리(Chlorops oryzae) 등 파리류 발 생량이 높았다. 천적군은 좀벌(Eulophidae), 고치벌(Braconidae), 맵시벌(Ichneumonidae) 등의 기생성 곤충류와 갈거미과(Pholcidae), 접시거미과(Linyphiidae) 등의 거미류(Araneae)가 우점하였으며, 기타 곤충군에서는 육서파리류인 노랑굴파리과(Chloropidae), 수 서파리류인 모기과(Culicidae) 등 파리목과 잎벌레과(Chrysomelida), 알꽃벼룩과(Helodidae) 등의 딱정벌레목이 대부분을 차지하였 다(Fig. 1).

조사기간 동안 해충저항성 $\mathrm{Bt}$ 벼 $(\mathrm{Bt}-\mathrm{T})$ 재배가 해충군, 천적군, 기타 곤충군 등 기능군별 발생양상에 미치는 영향을 분석하였으 며, 개체 발생량은 해충저항성 $\mathrm{Bt}$ 벼(Bt-T)와 모품종인 동진벼, 재배품종인 일미벼 재배지에서는 비슷한 수준으로 발생하였으 며, 채집된 전체 곤충류에서도 통계적 유의차가 나타나지 않았다 (Fig. 2A). 그 중 해충군의 발생은 총 7 목 17 과의 해충이 채집되었 고, 채집된 전체 해충류에서 멸구과와 매미충과가 우점한 매미목 곤충류가 $78.0 \%$ 를 차지하였다. 그 외에는 총채벌레목 $9.7 \%$, 파리목 $7.2 \%$, 딱정벌레목 $2.2 \%$, 노린재목 $1.4 \%$, 메뚜기목 $0.9 \%$, 
Table 1. Total sum number of common plant dwelling non-target insects and arachnids captured using vacuum suction at fields planted with three different genotypes of rices at Gunwi, Korea.

\begin{tabular}{|c|c|c|c|c|c|c|c|c|}
\hline \multirow{2}{*}{ Category } & \multirow{2}{*}{ Order } & \multirow{2}{*}{ Family } & \multicolumn{3}{|c|}{2016} & \multicolumn{3}{|c|}{2017} \\
\hline & & & $\mathrm{Bt}-\mathrm{T}^{\mathrm{z}}$ & Dongjin-byeo & Ilmi-byeo & Bt-T & Dongjin-byeo & Ilmi-byeo \\
\hline \multirow[t]{18}{*}{ Insect pests } & \multirow[t]{2}{*}{ Orthoptera } & Tettigoniidae & 6 & 5 & 8 & 0 & 2 & 4 \\
\hline & & Acrididae & 0 & 1 & 1 & 1 & 6 & 3 \\
\hline & Thysanoptera & Thripidae & 0 & 0 & 0 & 122 & 161 & 115 \\
\hline & \multirow[t]{5}{*}{ Hemiptera } & Miridae & 0 & 2 & 3 & 6 & 13 & 5 \\
\hline & & Berytidae & 1 & 1 & 0 & 1 & 0 & 0 \\
\hline & & Lygaeidae & 5 & 3 & 3 & 1 & 2 & 0 \\
\hline & & Coreidae & 2 & 1 & 0 & 0 & 1 & 0 \\
\hline & & Rhopalidae & 1 & 0 & 2 & 1 & 2 & 2 \\
\hline & \multirow[t]{4}{*}{ Homoptera } & Cicadellidae & 41 & 34 & 33 & 280 & 345 & 329 \\
\hline & & Derbidae & 3 & 0 & 1 & 0 & 0 & 0 \\
\hline & & Delphacidae & 393 & 361 & 429 & 243 & 284 & 313 \\
\hline & & Aphididae & 28 & 51 & 42 & 0 & 0 & 0 \\
\hline & \multirow[t]{2}{*}{ Coleoptera } & Chrysomelidae & 2 & 1 & 2 & 4 & 5 & 12 \\
\hline & & Curculionidae & 11 & 12 & 11 & 7 & 8 & 14 \\
\hline & Diptera & Chloropidae & 100 & 108 & 92 & 0 & 0 & 0 \\
\hline & \multirow[t]{2}{*}{ Lepidoptera } & Pyralidae & 0 & 1 & 0 & 3 & 5 & 9 \\
\hline & & Noctuidae & 0 & 2 & 2 & 0 & 0 & 2 \\
\hline & Subtotal & & 593 & 583 & 629 & 669 & 834 & 808 \\
\hline \multirow[t]{23}{*}{ Natural enemies } & Odonata & Coenagrionidae & 14 & 13 & 6 & 12 & 7 & 6 \\
\hline & \multirow[t]{3}{*}{ Hemiptera } & Saldidae & 0 & 0 & 0 & 7 & 3 & 1 \\
\hline & & Nabidae & 1 & 2 & 3 & 0 & 0 & 0 \\
\hline & & Anthocoridae & 26 & 18 & 13 & 13 & 14 & 13 \\
\hline & Neuroptera & Chrysopidae & 2 & 0 & 1 & 1 & 2 & 1 \\
\hline & \multirow[t]{2}{*}{ Coleoptera } & Staphylinidae & 26 & 14 & 17 & 2 & 2 & 6 \\
\hline & & Coccinellidae & 0 & 0 & 0 & 11 & 6 & 8 \\
\hline & \multirow[t]{5}{*}{ Hymenoptera } & Eulophidae & 59 & 70 & 59 & 192 & 211 & 267 \\
\hline & & Platygastridae & 24 & 27 & 11 & 1 & 2 & 4 \\
\hline & & Braconidae & 24 & 27 & 28 & 54 & 71 & 62 \\
\hline & & Ichneumonidae & 26 & 21 & 31 & 5 & 4 & 4 \\
\hline & & Drynidae & 3 & 2 & 7 & 0 & 0 & 0 \\
\hline & \multirow[t]{11}{*}{ Araneae } & Pholcidae & 101 & 91 & 109 & 73 & 76 & 70 \\
\hline & & Theridiidae & 5 & 1 & 5 & 1 & 3 & 8 \\
\hline & & Linyphiidae & 11 & 10 & 18 & 20 & 20 & 28 \\
\hline & & Araneidae & 2 & 0 & 2 & 0 & 2 & 4 \\
\hline & & Tetragnathidae & 7 & 4 & 8 & 3 & 1 & 4 \\
\hline & & Agelenidae & 7 & 5 & 5 & 18 & 20 & 36 \\
\hline & & Pisauridae & 2 & 3 & 3 & 1 & 0 & 0 \\
\hline & & Lycosidae & 0 & 0 & 0 & 2 & 3 & 3 \\
\hline & & Oxyopidae & 0 & 1 & 0 & 7 & 4 & 21 \\
\hline & & Clubionidae & 0 & 0 & 0 & 2 & 0 & 0 \\
\hline & & Salticidae & 2 & 3 & 1 & 23 & 36 & 16 \\
\hline
\end{tabular}


Table 1. Continued

\begin{tabular}{|c|c|c|c|c|c|c|c|c|}
\hline \multirow{2}{*}{ Category } & \multirow{2}{*}{ Order } & \multirow{2}{*}{ Family } & \multicolumn{3}{|c|}{2016} & \multicolumn{3}{|c|}{2017} \\
\hline & & & $B t-T^{z}$ & Dongjin-byeo & Ilmi-byeo & Bt-T & Dongjin-byeo & Ilmi-byeo \\
\hline \multirow[t]{2}{*}{ Natural enemies } & Araneae & Ctenidae & 0 & 0 & 0 & 0 & 1 & 0 \\
\hline & Subtotal & & 342 & 312 & 327 & 448 & 488 & 562 \\
\hline \multirow[t]{14}{*}{ Other insects } & Homoptera & Tingidae & 0 & 0 & 0 & 0 & 0 & 1 \\
\hline & Coleoptera & Helodidae & 6 & 1 & 5 & 25 & 15 & 22 \\
\hline & & Elateridae & 4 & 3 & 3 & 1 & 5 & 3 \\
\hline & & Chrysomelidae & 68 & 86 & 62 & 20 & 17 & 11 \\
\hline & & Curculionidae & 1 & 2 & 1 & 6 & 20 & 28 \\
\hline & Diptera & Culicidae & 128 & 91 & 97 & 32 & 34 & 48 \\
\hline & & Empididae & 0 & 0 & 0 & 4 & 3 & 2 \\
\hline & & Dolichopodidae & 9 & 6 & 4 & 33 & 29 & 41 \\
\hline & & Syripidae & 1 & 2 & 0 & 0 & 1 & 1 \\
\hline & & Phoridae & 7 & 18 & 16 & 0 & 0 & 0 \\
\hline & & Sciomyzidae & 9 & 12 & 14 & 10 & 7 & 9 \\
\hline & & Chloropidae & 271 & 236 & 247 & 219 & 269 & 238 \\
\hline & & Ephydridae & 23 & 15 & 24 & 113 & 124 & 94 \\
\hline & Subtotal & & 527 & 472 & 473 & 463 & 524 & 498 \\
\hline Total & & & 1,462 & 1,367 & 1,429 & 1,580 & 1,846 & 1,868 \\
\hline
\end{tabular}

${ }^{\mathrm{Z}}$ Insect-resistant genetically modified rice.

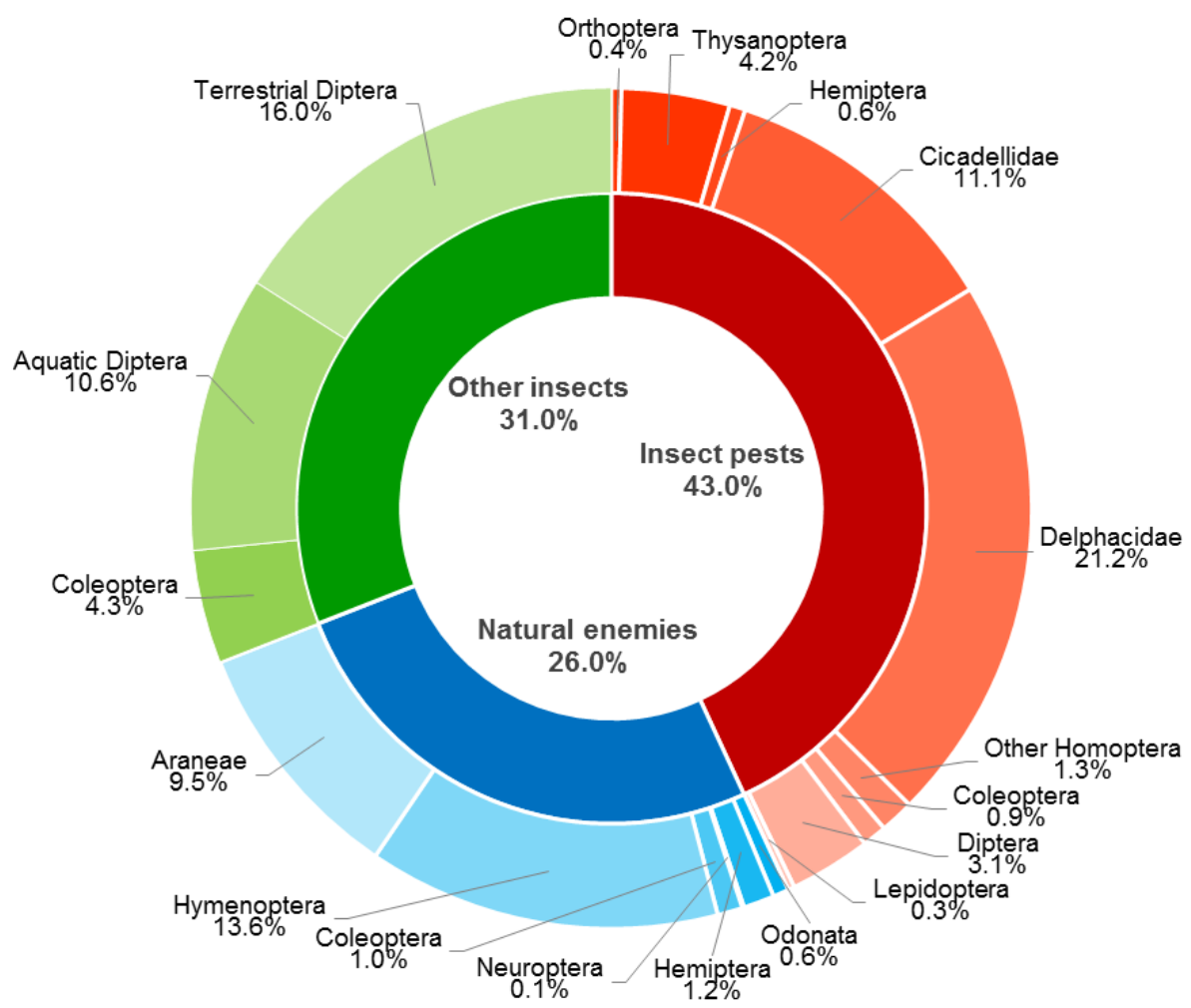

Fig. 1. Occurrences of common plant dwelling non-target insects and arachnids captured using vacuum suction on three different genotypes of rices. 
나비목 $0.6 \%$ 로 조사되었다. 노린재목을 제외하고 해충저항성 $\mathrm{Bt}$ 벼(Bt-T), 동진벼 및 일비벼 품종 간의 각 분류군별 발생에서는 통계적으로 유의차가 없었다(Fig. 2B). 천적군은 총 6 목 12 과의 곤충류와 12 과의 거미류가 채집되었으며, 벌목 $52.3 \%$ 로 우점하 였고, 거미류 $36.8 \%$, 노린재목 $4.6 \%$, 딱정벌레목 $3.7 \%$, 잠자리 목 $2.3 \%$, 풀잠자리목 $0.3 \%$ 의 비율로 조사되었으며, 해충저항성 $\mathrm{Bt}$ 벼(Bt-T), 동진벼 및 일미벼 품종간의 분류군 발생에서는 통계 적으로 유의차는 없었다(Fig. $2 \mathrm{C}$ ). 천적군과 해충군을 제외한 기타 곤충군은 총 3 목 13 과의 곤충들이 채집되었으며, 노랑굴파 리과(Chloropidae), 벼룩파리과(Phoridae), 춤파리과(Empididae), 꽃등애과(Syripidae)가 포함된 육서파리류가 $51.61 \%$, 모기과 (Culicidae), 물가파리과(Ephydridae), 장다리파리과(Dolichopodidae), 뿔들파리과(Sciomyzidae)가 포함된 수서파리류가 $34.32 \%$ 로 총 파리목이 $85.93 \%$ 로 우점하였고, 딱정벌레목 $14.04 \%$, 매미목 $0.03 \%$ 로 조사되었다. 해충저항성 $\mathrm{Bt}$ 벼(Bt-T), 동진벼와 일미벼 품종간의 분류군별 곤충류 발생에서는 통계적 유의 차이는 없었 다(Fig. 2D). 따라서 해충저항성 $\mathrm{Bt}$ 벼(Bt-T)는 모품종인 동진벼와 재배품종인 일미벼에서 혹명나방(Cnaphalocrocis medinalis)과 이화명나방(Chilo suppressalis) 등 표적해충을 제외한 해충군 및 천적군, 기타 곤충군에 대한 전체적인 발생밀도에서는 통계적
유의차가 보이지 않았다. 이와 같은 결과는 해충저항성 $\mathrm{Bt}$ 벼(Bt-T) 가 모품종과 재배품종에 비교하여 재배지 내의 곤충상 발생 양상 에 특이적인 영향을 미치지 않는 것으로 판단되었다.

해충저항성 $\mathrm{Bt}$ 벼(Bt-T), 동진벼와 일미벼의 격리 포장 재배시 에 조사 시기별 곤충 발생 양상에 차이가 나타나는지를 분석하였 다. 2016년에서는 개체군의 밀도는 3 품종 모두에서 생육초기부 터 생육후기로 갈수록 개체군밀도가 증가하였으며, 9월 23일에 개체군 밀도가 가장 높게 증가하였다가 마지막 채집일인 10 월 9일에 감소한 경향을 보였다. 전반적으로 해충저항성 $\mathrm{Bt}$ 벼(Bt-T) 와 동진벼 및 일미벼에서 조사시기별 개체군 밀도의 차이는 보였으나, 동일 조사시기 내에서는 통계적 유의성이 없었다(Fig. 3). 2017년에서도 생육초기부터 생육후기로 갈수록 개체군밀도 가 증가한 경향을 보였으며, 8월 11일에까지 증가한 후, 이후에도 밀도가 어느 정도 지속되는 경향을 보였으나, 해충저항성 $\mathrm{Bt}$ 벼 $(\mathrm{Bt}-\mathrm{T})$ 와 동진벼 및 일미벼 품종에 따라 10 월 7 일에 최대 밀도를 보이기도 하였다. 2017년도에도 해충저항성 $\mathrm{Bt}$ 벼(Bt-T), 동진벼 및 일미벼 품종간의 조사시기별 개체군 밀도의 차이는 보였으나, 동일 조사시기 내에서는 통계적인 유의성은 없었다(Fig. 3). 해충 저항성 $\mathrm{Bt}$ 벼(Bt-T)와 동진벼 및 일미벼에서 생육시기에 따른 연차별 총 8 회의 조사 기간별 통계적인 유의한 차이는 보이지
A

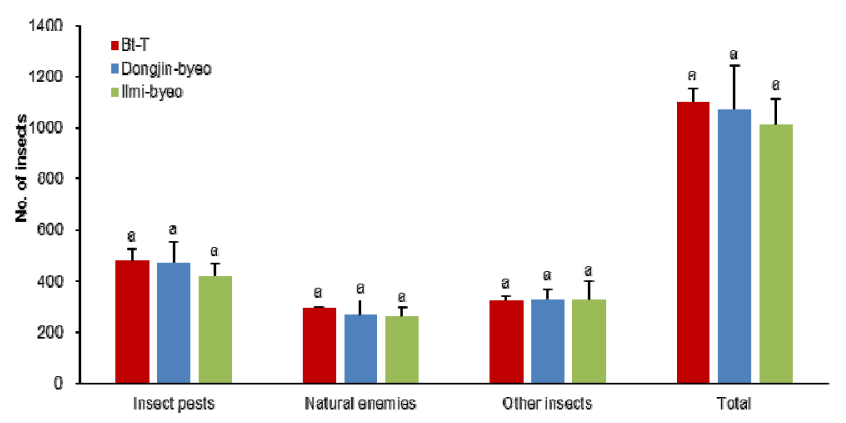

C

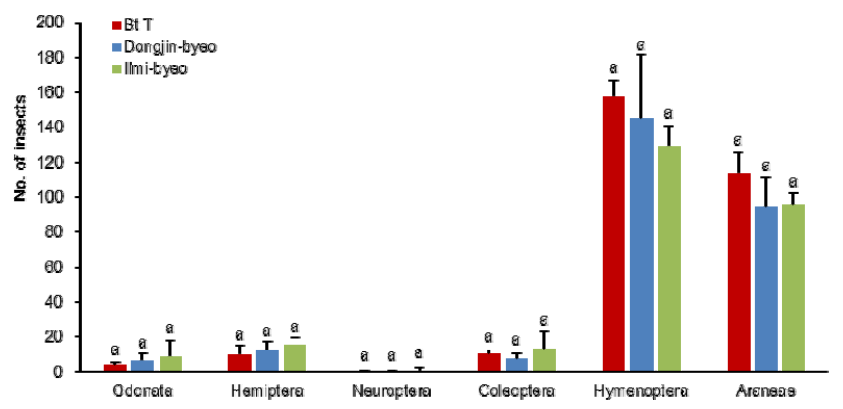

B

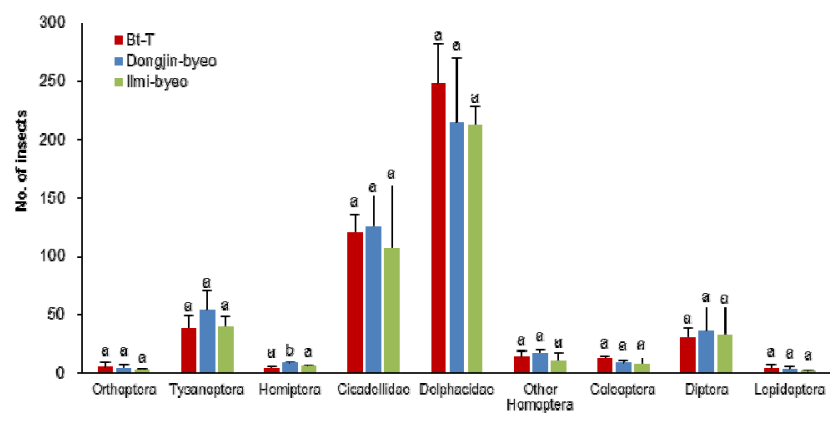

D

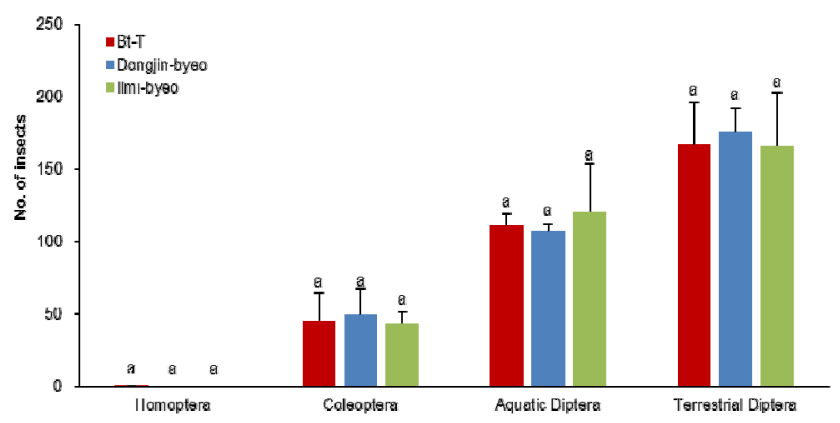

Fig. 2. Average population densities of insect by rice variety in LMO field. A) Average population densities of insect groups. B) Average population densities of non-target insect pests. C) Average population densities of natural enemies. D) Average population densities of other insects. The results shown are the mean $\pm \mathrm{SD}, \mathrm{n}=3$ replicates for each group. Bt-T: insect-resistant genetically modified rice. a: Duncan's Multiple Range Test at $p<0.05$. 
않았으며, 따라서 해충저항성 $\mathrm{Bt}$ 벼(Bt-T)가 시기별 곤충상 발생 에도 특별한 영향을 미치지 않는 것으로 판단되었다.

2016년과 2017년에 해충저항성Bt벼(Bt-T)와 동진벼 및 일미 벼의 재배지에서 채집된 곤충상의 군집 분석을 전체 채집된 곤충에서 우점도 지수(DI)는 최소 0.23 에서 최대 0.24 로 높지 않은 것으로 분석되었는데 이는 채집된 대상 군집 내 모든 개체수 가 다양하게 구성되고 있음을 나타내고 있다. 풍부도 지수(RI)는 벼 품종별로 해충저항성 $\mathrm{Bt}$ 벼(Bt-T)와 일미벼 재배 포장에서 각각 7.52, 7.57을 보여 동진벼 포장의 7.66보다 조금 낮게 나타났 으나 통계적인 유의적 차이는 보이지 않았다. 다양도 지수 $\left(\mathrm{H}^{\prime}\right)$ 는 해충저항성 $\mathrm{Bt}$ 벼(Bt-T)와 동진벼 및 일미벼의 재배 포장에서 3.08 3.10의 값으로 품종간 통계적인 유의성은 없었으며, 이 결과는 종 다양도가 풍부한 지역인 습지의 약 2.7 - 4.0범위의 값을 보였다(Choi et al. 2015). 또한, 균등도 지수(EI)는 0.77 0.78 로 분석되어 대체적으로 해충저항성 $\mathrm{Bt}$ 벼(Bt-T)와 non-GM 벼인 동진벼와 일미벼의 재배지에서 다양한 종들이 채집되었으 며, 개체수의 특이적인 차이가 없었음을 알 수 있었다(Table 2). 이와 같은 결과는 Protox 제초제 저항성벼와 모품종인 동진벼를
$\mathrm{LMO}$ 에서 재배한 후, 곤충 발생을 비교한 결과에서도 non-GM벼 와 $\mathrm{GM}$ 벼의 통계적인 유의 차이가 없다고 하여 본 실험 결과와 같은 결과를 보였다( $\mathrm{Bae}$ et al. 2012).

벼의 유전자 변형으로 인해 벼 재배 시 곤충상에 변화가 발생하 는지를 확인하기 위하여, 2년에 걸쳐 해충저항성 $\mathrm{Bt}$ 벼(Bt-T)와 동진벼 및 일미벼의 품종별로 총 16 회 채집하여 얻은 곤충상 데이터를 주성분 분석법을 이용하여 통계분석을 하였다. 총 54 개 의 곤충류와 거미류에 대한 데이터를 주성분 분석을 수행하고 그 결과를 score plot으로 확인한 결과, 2016년과 2017년 각각에 서 동일하게 해충저항성 $\mathrm{Bt}$ 벼(Bt-T, GM)와 동진벼(DJ) 및 일미 벼(IM) 간 곤충상 차이를 보이지 않았다(Figs. $4 \mathrm{~A}, 4 \mathrm{~B})$. 이 때, 해충저항성 $\mathrm{Bt}$ 벼(Bt-T, $\mathrm{GM})$ 와 모품종인 동진벼(DJ) 간의 차이 뿐만이 아니라 해충저항성 $\mathrm{Bt}$ 벼(Bt-T, GM)와 재배품종인 일미 벼(IM) 간에도 곤충상의 차이는 없었다. 다만, 2017년에 일비벼 재배 포장에서 3회 채집한 결과 중 1 회가 나머지 곤충상과 차이를 보였다. 다음으로 재배 연차별 데이터를 구분하지 않고, 모든 데이터를 포함하여 주성분 분석을 수행하였다. 그 결과, 곤충상 의 차이는 재배한 해충저항성 $\mathrm{Bt}$ 벼(Bt-T)와 동진벼 및 일미벼의

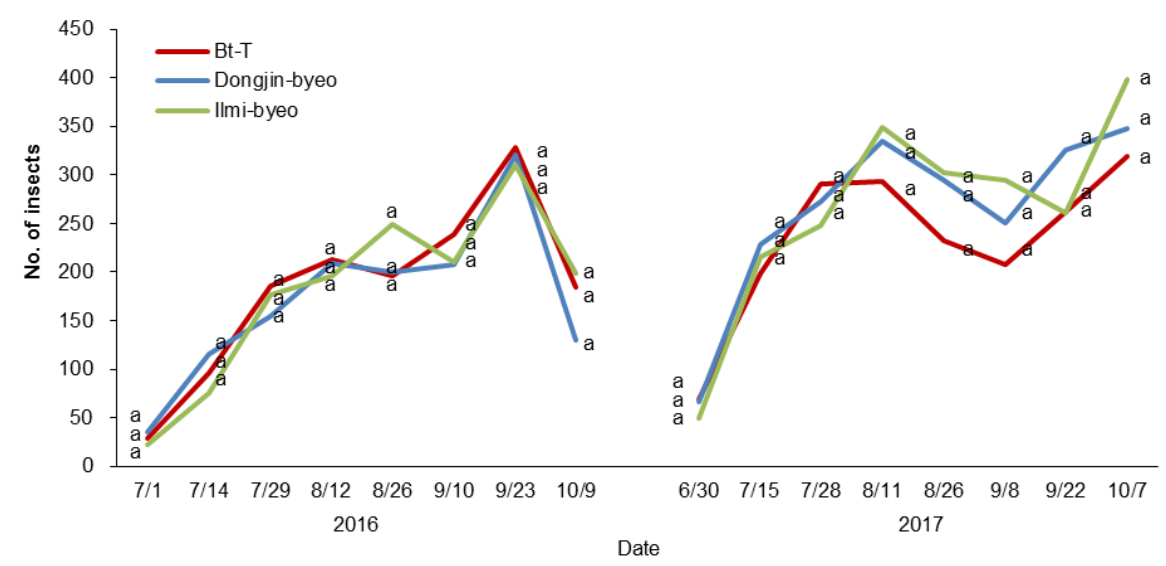

Fig. 3. Seasonal fluctuations of common plant dwelling non-target insects by rice variety. Bt-T: insect-resistant genetically modified rice. a: Duncan's Multiple Range Test at $p<0.05$

Table 2. Analysis of insect diversity in common plant dwelling non-target insect groups and arachnid captured using vacuum suction at fields planted with three different genotypes of rices at Gunwi, Korea.

\begin{tabular}{lccc}
\hline Indices & Bt- $^{\mathrm{z}}$ & Dongjin-byeo & Ilmi-byeo \\
\hline Dominance (DI) & $0.23 \pm 0.04 \mathrm{a}^{\mathrm{y}}$ & $0.24 \pm 0.02 \mathrm{a}$ & $0.24 \pm 0.01 \mathrm{a}$ \\
Richness (RI) & $7.52 \pm 0.43 \mathrm{a}$ & $7.66 \pm 0.10 \mathrm{a}$ & $7.57 \pm 0.41 \mathrm{a}$ \\
Diversity (H') & $3.10 \pm 0.19 \mathrm{a}$ & $3.08 \pm 0.07 \mathrm{a}$ & $3.09 \pm 0.07 \mathrm{a}$ \\
Evenness (EI) & $0.78 \pm 0.04 \mathrm{a}$ & $0.77 \pm 0.02 \mathrm{a}$ & $0.78 \pm 0.01 \mathrm{a}$ \\
\hline
\end{tabular}

${ }^{\mathrm{z}}$ Insect-resistant genetically modified rice.

${ }^{\mathrm{y}}$ The results shown are the mean $\pm \mathrm{SD}, \mathrm{n}=3$ replicates for each group, and Duncan's Multiple Range Test at $p<0.05$ within three different genotypes. 
품종이 아닌 재배 시기에 따라 확연한 차이가 있음을 확인 할 수 있었다(Fig. 4C). 주성분 1과 2로 나타낸 score plot에서 보여지 듯이 총 변이의 $36.6 \%$ 를 포함하는 주성분 1 에 의해 곤충상은 재배 시기 즉, 2016년과 2017년으로 구분이 되었다. 이 때에도 Fig. 4B에서 나타난 결과와 동일하게 2017년 일미벼 재배 포장에 서 채집한 곤충상 중 1 회가 다른 곤충상과 차이를 보였다. 이러한 해충저항성 $\mathrm{Bt}$ 벼(Bt-T, $\mathrm{GM})$ 와 모품종인 동진벼(DJ)의 재배 연 차별 차이 및 특정 샘플링에서 곤충상 차이가 나타나는데 있어 어떤 곤충이 가장 많은 영향력을 미쳤는지 알아보기 위하여, 주성분 분석 결과를 loading plot으로 확인하였다. 주성분 1 에 의해 진딧물과(Aphididae, 12)와 노랑굴파리과(Chloropidae, 15)가 plot의 오른쪽에, 총채벌레과(Thripidae, 3)이 가장 왼쪽에 위치하였다. 데이터를 확인한 결과, 진딧물과와 노랑굴파리과는 2016년에만 채집이 되었고, 2017년에는 벼 재배 포장에서 채집 되지 않았다. 반대로, 총채벌레과(Thripidae)는 2017년에만 채집 이 되었다. 맵시벌과(Ichneumonidae, 28)는 2017년 재배 포장과
비교해 2016년에 6배 더 많이 채집이 된 반면, 매미충과 (Cicadellidae, 9)와 좀벌과(Eulophidae, 25)는 2017년 포장에서 각각 8 배 및 3 배 이상 많이 채집되었다. 주성분 1 과 2 에 의해 loading plot의 왼쪽 위에 위치한 변수가 2017년 일미벼의 곤충상 특이성에 영향을 미쳤을 것으로 보여지며, 실제로 왕거미과 (Araneidae, 33) 와 방패벌레과(Tingidae, 42) 가 일비벼 포장의 3 회 채집 중 1 회에서만 발견됨을 데이터에서 확인 할 수 있었다. 이를 통해, 복잡한 데이터에서 유의미한 결과를 도출하는데 있어 주성분 분석이 유용한 통계 방법임을 다시 한번 확인할 수 있었다. 주성분 분석 결과를 종합해 보면, 벼의 게놈에 $m c r y l A c l$ 유전자 를 도입하여 개발된 해충저항성 $\mathrm{Bt}$ 벼(Bt-T)는 모품종인 동진벼 및 일반 재배 품종인 일미벼와 비교하여 재배지의 곤충상 변화에 영향을 미치지 않음을 알았다. 이러한 결과는, $\gamma-T M T(\gamma$ -tocopherol methyltransferase) 유전자가 도입된 비타민 $\mathrm{E}$ 강화 콩을 대상으로 곤충상 변화를 확인한 이전의 연구 결과와 동일한 것으로, 그 연구에서 $\mathrm{GM}$ 콩이 모품종과 비교해 재배 포장 내의
A

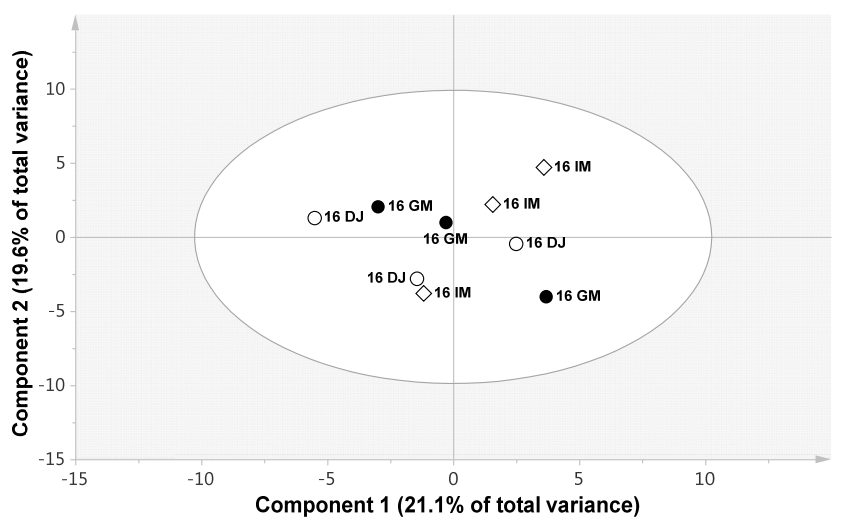

C

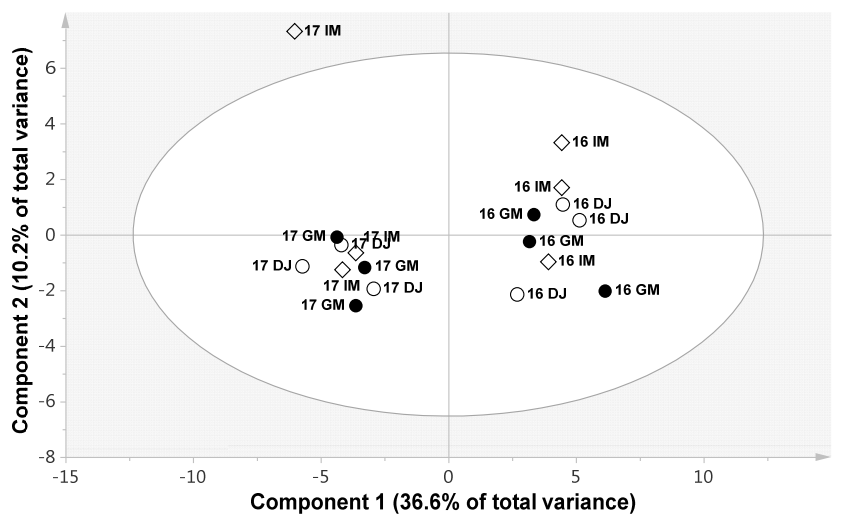

B

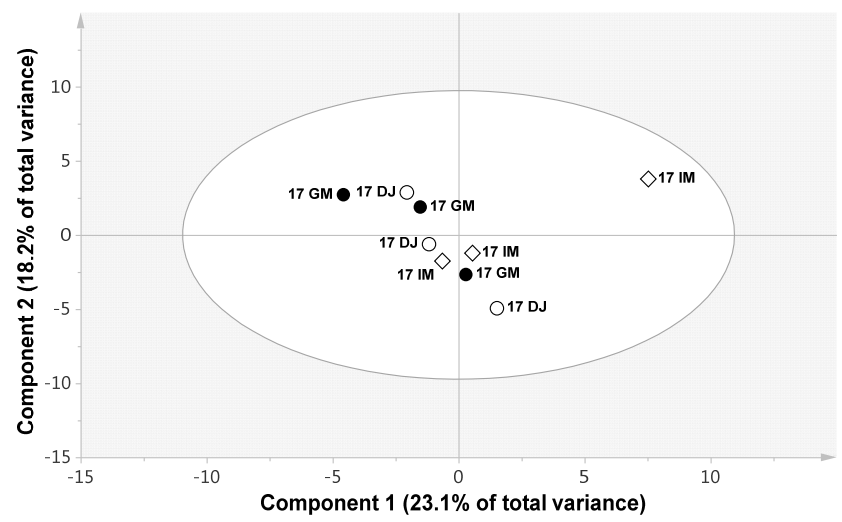

D

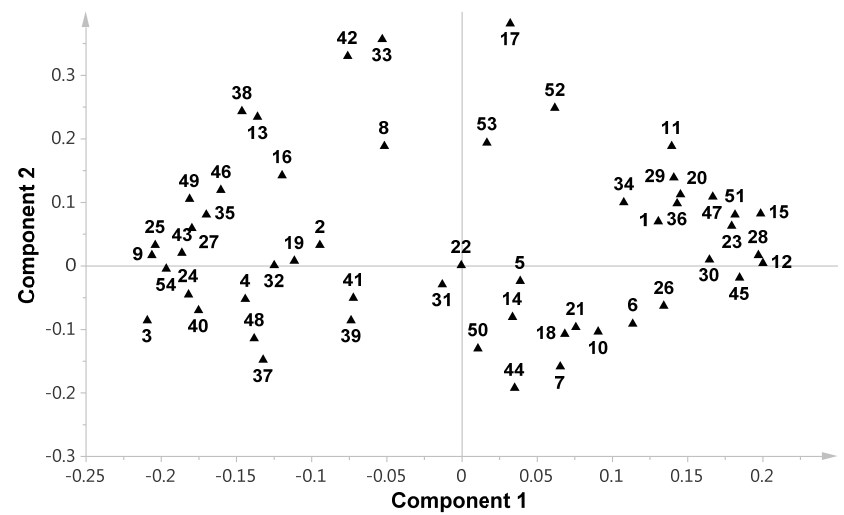

Fig. 4. Score plots of principal components 1 and 2 of the PCA results obtained from data on 54 insects collected at fields planted with three different genotypes of rice plants in two years, 2016 (A) and 2017 (B). Score (C) and loading plots (D) of principal components 1 and 2 of the PCA results obtained from data on 54 insects collected at fields planted with three different genotypes of rice plants in two years, 2016 (16) and 2017 (17). The numbers of the loading plots represent the same compounds as for Table 1. GM, insect-resistance genetically modified rice (Bt-T); DJ, parent cultivar (Dongjin byeo); IM, commercial rice cultivar (Ilmi byeo). 
곤충상에 영향을 미치지 않은 결과를 얻었었다(Oh et al. 2017). 본 연구에서는 2 년 간의 곤충상 데이터를 통해, 유전자 변형이 아닌 작물의 재배 시기가 오히려 곤충상 변화에 큰 영향을 끼치는 요인임을 새롭게 확인 할 수 있었다.

\section{적 요}

본 연구는 토양 세균인 B. thuringiensis에서 유래한 해충저항성 유전자 $(\mathrm{ry} / \mathrm{Ac})$ 를 일미벼에 도입시킴으로써 혹명나방(Cnaphalocrocis medinalis)에 대하여 살충성을 나타내는 해충저항성 $\mathrm{Bt}$ 벼(Bt-T) 의 환경위해성 평가에 대한 프로토콜 및 가이드라인을 개발하고 자 수행하였다. 경북대학교 군위 LMO 격리포장에서 2년간 해충 저항성 $\mathrm{Bt}$ 벼 $(\mathrm{Bt}-\mathrm{T})$ 와 모품종인 동진벼 및 재배 품종인 일미벼를 재배하고, 혹명나방 등 표적곤충을 제외한 곤충류와 거미류가 포함한 다양성을 조사를 2016년과 2017년에 수행하였다. 조사기 간 동안 채집된 개체들은 벼에 대한 기능별로 해충군, 천적군, 기타 곤충군으로 크게 구분하여 동정 계수하였으며, 2년간 총 11 목 51 과 9,552 개체가 채집되었다. 해충저항성 $\mathrm{Bt}$ 벼 $(\mathrm{Bt}-\mathrm{T})$, 동 진벼 및 일미벼에서 각각 $3,042,3,213,3,297$ 개체가 채집되었다. 조사된 개체군의 해충군, 천적군, 기타 곤충의 발생량은 해충군에 서 노린목을 제외하고 해충저항성 $\mathrm{Bt}$ 벼(Bt-T)과 모품종인 동진벼 와 재배품종인 일미벼 품종 간의 각 분류군별 발생에서 통계적인 유의차가 없었으며, 시기별 곤충 발생 양상에서도 통계적인 유의 적 차이를 보이지 않았다. 2년간의 곤충상 데이터를 주성분 분석 법으로 분석한 결과, 2016년과 2017년 각각에서 동일하게 해충저 항성 $\mathrm{Bt}$ 벼(Bt-T)와 동진벼 및 일미벼 품종간의 곤충상 차이를 보이지 않았으나, 재배 시기에 따라 확연한 차이가 있음을 확인하 였다. 유전자 변형에 의한 품종간의 차이 보다는 작물의 재배 시기에 따라 곤충상 변화에 큰 영향을 끼치는 요인임을 새롭게 확인 할 수 있었다.

\section{사 사}

본 연구는 농촌진흥청 차세대 바이오그린21사업(과제번호: PJ013680)의 지원에 의해 이루어진 것임.

\section{REFERENCES}

1. Bae SM, Yu MR, Yun HG, Shin TY, Choi JB, Lee WW,
Kim HJ, Kim HT, Woo SD. 2012. Assessment of insects in transgenic rice (CPPO06) resistant to the herbicide. J Agric Sci Chungbuk Nat'l Univ 28: 137-142.

2. Choi WS, Ahn SJ, Yoon JH, Kim HH, Jang JW, Park JJ. 2015. Comparing of insect fauna between transgenic rice and common rice cultivar based on light tap and sweeping methods. J Agric Life Sci 49: 1-17.

3. Gullan PK, Cranston PS. 2005. The insect an outline of entomology. Blackwell Publishing Ltd. Oxford, UK.

4. James C. 2018. Global status of commercialized biotech/GM crops: 2017, ISAAA BRIEF No. 53 (http://www.isaaa.org).

5. Kim KM, Ryu TH, Suh SJ. 2010. Studies on insect diversity related to genetically engineered vitamin A rice under large scale production. Korean J Breed Sci 42: 157-162.

6. Lee BK. 2017. A study on the establishment of isolation distances for environmental release of biotech crops. Kor J Agric Sci 44: 188-195.

7. Lee HS, Yi GH, Kim KM. 2012. Comparison of weed characteristics and possibility of gene flow in GM rice. Kor J Weed Sci 32: 10-16.

8. Lee SY, Yeo YS, Park SY, Oh SW, Yoon EK, Shin KS, Woo HJ, Lim MH. 2015. Composition analysis of herbicide tolerant $\mathrm{Ab}$ rice and insect-resistant $\mathrm{Bt}$ rice. Korean $\mathrm{J}$ Breed Sci 47: 255-263.

9. Lee W, Yeo Y, Oh S, Cho KS, Park YE, Park SK, Lee SM, Cho HS, Park SY. 2017. Compositional analyses of diverse phytochemicals and polar metabolites from different-colored potato (Solanum tubersum L.) tubers. Food Sci. Biotech 26: $1379-1389$.

10. Oh SD, Kim JS, Lee KJ, Ryu TH, Suh SJ. 2014. Studies on insect diversity related to drought-tolerant transgenic (Agb0103) rice under large scale GMO field. Korean J Breed Sci 46: 136-142.

11. Oh SD, Suh SJ, Park SY, Lee K, Sohn SI, Yun DW, Chang AC. 2017. Effects of vitamin $E$ enhanced transgenic soybean cultivation on insect diversity. Korean J Breed Sci 49: 129-140.

12. Son SM. 2001. Rice based meal for prevention of obesity and chronic disease. Kor J Comm Nutr 6: 862-867.

13. Price PW. 1997. Insect Ecology. John Wiley and Sons, New York, USA.

14. Qin Y, Kim SM, Park HY, Sohn JK. 2009. Inheritance analysis of giant mutation induced by T-DNA insertion in rice. Korean J Breed Sci 41: 9-15. 